\title{
Current State of Knowledge about Role of Pets in Zoonotic Transmission of SARS-CoV-2
}

\author{
Mateusz Dróżdż 1,*(D), Paweł Krzyżek ${ }^{2}$ (D), Barbara Dudek ${ }^{3}$, Sebastian Makuch ${ }^{4}$ (D), Adriana Janczura ${ }^{2}$ (D) \\ and Emil Paluch $2, *$ (D)
}

check for updates

Citation: Dróżdż, M.; Krzyżek, P.; Dudek, B.; Makuch, S.; Janczura, A.; Paluch, E. Current State of Knowledge about Role of Pets in Zoonotic Transmission of SARS-CoV-2. Viruses 2021, 13, 1149. https://doi.org/10.3390/v13061149

\section{Academic Editors:}

Magdalena Materniak-Kornas and Jacek Kuźmak

Received: 27 May 2021

Accepted: 11 June 2021

Published: 16 June 2021

Publisher's Note: MDPI stays neutral with regard to jurisdictional claims in published maps and institutional affiliations.

Copyright: (c) 2021 by the authors. Licensee MDPI, Basel, Switzerland. This article is an open access article distributed under the terms and conditions of the Creative Commons Attribution (CC BY) license (https:/ / creativecommons.org/licenses/by/ $4.0 /)$.
1 Laboratory of RNA Biochemistry, Institute of Chemistry and Biochemistry, Freie Universität Berlin, Takustraße 6, 14195 Berlin, Germany

2 Department of Microbiology, Wrocław Medical University, St. T. Chałubińskiego 4, 50-376 Wrocław, Poland; pawel.krzyzek@umed.wroc.pl (P.K.); adriana.janczura@umed.wroc.pl (A.J.)

3 Laboratory of Microbiology, Private Health Care Institution, St. Jana Pawła II, 41-100 Siemianowice Śląskie, Poland; basia269@op.pl

4 Department of Pathology, Wrocław Medical University, St. K. Marcinkowskiego 1, 50-368 Wrocław, Poland; sebastian.mk21@gmail.com

* Correspondence: m.drozdz@fu-berlin.de (M.D.); emil.paluch@umed.wroc.pl (E.P.)

\begin{abstract}
Pets play a crucial role in the development of human feelings, social life, and care. However, in the era of the prevailing global pandemic of COVID-19 disease caused by the severe acute respiratory syndrome coronavirus 2 (SARS-CoV-2), many questions addressing the routes of the virus spread and transmission to humans are dramatically emerging. Although cases of SARS-CoV-2 infection have been found in pets including dogs, cats, and ferrets, to date there is no strong evidence for pet-to-human transmission or sustained pet-to-pet transmission of SARS-CoV-2. However, an increasing number of studies reporting detection of SARS-CoV-2 in farmed minks raises suspicion of potential viral transmission from these animals to humans. Furthermore, due to the high susceptibility of cats, ferrets, minks and hamsters to COVID-19 infection under natural and/or experimental conditions, these animals have been extensively explored as animal models to study the SARS-CoV-2 pathogenesis and transmission. In this review, we present the latest reports focusing on SARS-CoV-2 detection, isolation, and characterization in pets. Moreover, based on the current literature, we document studies aiming to broaden the knowledge about pathogenicity and transmissibility of SARS-CoV-2, and the development of viral therapeutics, drugs and vaccines. Lastly, considering the high rate of SARS-CoV-2 evolution and replication, we also suggest routes of protection against the virus.
\end{abstract}

Keywords: SARS-CoV-2; COVID-19; pets suitable animal models; zoonotic potential

\section{Introduction}

Due to the prevailing pandemic of the coronavirus disease (COVID-19) caused by severe acute respiratory syndrome coronavirus 2 (SARS-CoV-2), we are forced to observe physical isolation, the reason of which is confirmed human-to-human virus transmission. As of May 2021, a total of 192 countries and territories have documented nearly 170 million confirmed COVID-19 cases and 3.5 million related deaths [1]. The dramatically increasing number of cases adversely affected the global economy, tourism, and the health sectors [2].

The ownership of a companion animal, such as a dog or a cat, is a well-known factor in providing considerable health, social and emotional benefits to their owners. However, at the beginning of COVID-19 pandemic, social anxiety and the psychological repercussions of anecdotal media reports regarding the role of pets in SARS-CoV-2 transmission to humans lead to a dramatic increase in pet abandonment [3]. Nevertheless, over time, reports indicated a low probability of SARS-CoV-2 transmission from pets to humans, hence social anxiety has been brought under control. During an online survey carried out in December $2020,10 \%$ of respondents from the United States reported acquiring a new pet. This is an 
increase of $3 \%$ compared to May of the same year, when $7 \%$ of respondents acquired a new pet [4]. Furthermore, in Israel, Morgan et al. concluded that the interest of the dog adoption increased significantly in 2020, while dog abandonment did not change [3]. In contrast, in Poland, dog and/or cat adoptions remained constant or slightly increased, while significantly less quadrupeds were abandoned and surrendered to animal shelters. For instance, data from the inspection in the animal shelter in Gdynia, in northern Poland, indicates that in 2020,693 dogs were abandoned and delivered to the animal shelter. This is a significant decrease compared with the number of abandoned dogs in 2019 (more than 1000 dogs were abandoned and delivered to the animal shelter in this year) [5]. This decreasing frequency is likely associated with the supportive effect of pets during the loneliness of lockdown and a positive impact on humans' health and well-being.

When deciding to adopt and keep a pet, it is crucial to be aware that the low probability of SARS-CoV-2 transmission to a human does not mean such cases cannot occur. Data concerning its pathogenicity, routes of transmission, and strategies of elimination are still scarce. When analyzing the current literature indicating the direct or indirect correlation between animals and SARS-CoV-2 detection, as well as the frequent close contact between humans and animals, it is likely that, over time, not only human-to-animals transmission may occur, but also the reverse. Firstly, it is now widely accepted that wild fauna, most likely bats, constitute the primary reservoir of the SARS-CoV-2. Zhou et al. showed that the whole genomic sequence of bat coronavirus (bat-CoV) designated as RaTG13 is $96 \%$ identical to that of SARS-CoV-2 [6], suggesting that these viruses originate from bats. Furthermore, recent studies found that Malayan pangolins (Manis javanica) are frequently infected with CoVs. For instance, Li et al. indicated that pangolin-CoVs belonged to two different lineages. One lineage shared $97.4 \%$ amino acid identity to the receptor-binding domain (RBD) of the spike protein of SARS-CoV-2. Therefore, pangolins are considered to be a potential intermediate host for SARS-CoV-2 [7]. Secondly, the first reports of COVID-19 disease came from a "wet market", named Huanan Seafood Market in Wuhan, China, where live, wild-caught animals and livestock are commonly sold. Due to these circumstances, it has been hypothesized that animals are involved in the spillover of SARSCoV-2 [2]. Thirdly, it has been determined that SARS-CoV-2 belongs to the same family of viruses as SARS-CoV and Middle East respiratory syndrome coronavirus, designated as MERS-CoV. In the past, these viruses led to severe human diseases due to their transmission from animals to humans (SARS-CoV was associated with civet cats, while MERS-CoV was associated with dromedary camels) [8]. In 2002-2003, the first event occurred in China when SARS-CoV, which originated in bats, moved to humans, with palm civet cats being their intermediate host [9]. Recently, Sharma et al. evidenced the high phylogenetic similarity (approximately 79\% similarity) of SARS-CoV-2 to SARS-CoV [10]. The second outbreak of human CoVs was caused by MERS-CoV and occurred in 2012 in Saudi Arabia. The virus was transmitted from bats to humans with dromedary camels acting as their intermediate host [11]. It was reported MERS-CoV infected about 2494 people, with 858 fatalities. Lastly, several studies suggest that captive animals such as farmed minks can directly infect humans with SARS-CoV-2, raising questions regarding their potential role in the virus circulation in the world $[8,12,13]$. Taken together, the SARS-CoV-2 outbreak may be fueled by zoonotic transmission from animals, including companion ones, to humans.

It is worth noting, that not only are the lives of human beings at risk, but there is an equal potential threat to the animal world via reverse human to animal transmission. Due to the fact that pets, especially dogs and cats, are in close contact with humans and inhabit the same environment, these animals are thought to be highly exposed to human pathogens including SARS-CoV-2 [12]. In this review, we reported cases of SARS-CoV-2 isolation from companion animals, such as cats, dogs, and ferrets, in order to identify potential zoonotic transmission from pets to humans, from pets to pets, and from humans to pets. Furthermore, in light of the fact that cats, mustelids (such as ferrets and minks), and hamsters are highly susceptible to COVID-19 infection under natural and/or experimental 
conditions, we made a juxtaposition of reports that use these animals as models to study pathogenicity, routes of transmission and development of vaccines and antiviral drugs.

\section{The Potential Risk of SARS-CoV-2 Transmission from Animals and the Role of ACE2 Receptors}

SARS-CoV-2 uses angiotensin-converting enzyme 2 (ACE2) as a receptor for virus entry. Along with cell surface transmembrane serine protease 2 (TMPRSS2), viral fusion is carried out by the cleavage of receptor-binding domain (RBP) of viral spike protein. Sreenivasan et al. indicated that human ACE2 possess 24 amino acid residues that are required to bind the spike protein of SARS-CoV-2. Thus, any species that possesses similar amino acid residues would likely be susceptible hosts [14]. This discovery significantly increased the number of studies aiming to identify the structure of ACE2 in a variety of animal species. By comparing its similarity with human ACE2, it is possible to find animal models that contribute to the understanding of SARS-CoV-2 pathogenicity and routes of transmission. For instance, Luan et al. performed homology modelling of SARS-CoV-2 spike protein with ACE2 of several mammalian species, including companion animals. Based on the multi-scale computational approaches, authors predicted that SARS-CoV-2 could bind to ACE2 of ferrets, dogs, cats, hamsters, marmosets, and naked mole-rats, suggesting a broad host spectrum of the virus. The strength of association between the spike protein of SARS-CoV-2 and orthologues of ACE2 and TMPRSS2 was also analyzed in 215 vertebrate species [15]. Furthermore, Zhao et al. determined that dogs, cats, rabbits, and pangolins showed greater than $50 \%$ of hACE2 (human ACE2) binding, which indicates the high susceptibility of these species to SARS-CoV-2 [16]. The similarity of the ACE2 receptors with that of humans correlates relatively well with their infectivity. This may contribute to the risk of animal-to-human transmission of SARS-CoV-2 from animals having a high similarity ACE2 receptors to hACE2. It should be emphasized, however, that the there are many other factors that may favor or affect this transmission.

\section{SARS-CoV-2 Detection in Cats and Their Zoonotic Potential}

Cats are ranked as the second most common pets worldwide, followed by dogs. According to the 2020 American Veterinary Medical Association, in Canada alone, 48\% of inhabitants own one or more cats, while $25 \%$ of US households own at least one cat [17]. Taking into account COVID-19 infections in pets under natural conditions, cats are more sensitive to SARS-CoV-2 than dogs [18]. Since the beginning of COVID-19 pandemic, 126 outbreaks of SARS-CoV-2 isolation from pet cats have been reported (67 outbreaks in the US and 59 outbreaks in other countries and areas; data: February 2021) [19].

The first report of SARS-CoV-2 isolation from pet cats comes from New York City, New York, the US. Two cats with mild respiratory illnesses were thought to have contracted the virus from people in their households or neighborhoods [20]. The reverse zoonotic transmission of SARS-CoV-2 was also observed in several independent studies in Hong Kong, China [21,22]. For instance, in March 2020, viral RNA was detected in the oral cavity, nasal, and rectal swab samples from a clinically healthy pet cat whose owner was infected with the virus [21]. In another study, 6 of $50(12 \%)$ cats living with humans with SARS-CoV-2 infection were tested positive [22]. Also in China, this time in Wuhan - the epicenter of the COVID-19 pandemic, SARS-CoV-2 was detected from cats from three sources: animal shelters, pet hospitals, and COVID-19 patient families. A total of 102 serum samples were collected from these cats after the COVID-19 outbreak. SARS-CoV-2 was detected in 15 samples (14.7\%). Among them, $11(10.8 \%)$ had the viral neutralizing antibodies. This relatively high percentage of seropositivity in cats could be related to the large number of infected human cases having contact with pets [23]. Another case of human-to-cat transmission of SARS-CoV-2 was reported in Chile. On 5 May 2020, the cat-owners tested positive for SARS-CoV-2. Two days later, the male cat showed mild respiratory symptoms and tested positive. Four days after the male cat, the two female cats became positive, although asymptomatically. Additionally, one human and one cat showed antibodies against SARS-CoV-2 [24]. 
Including European countries, feline cases of COVID-19 have been reported in Belgium [25], Italy [26-29], the Netherlands [30], Spain [31,32], France [33,34], Germany [18], Switzerland [35], Russia [36], Croatia [37], Latvia [38], Greece [39] and the United Kingdom $[40,41]$. The first case of SARS-Co-V-2 isolation in pet cats in Europe was reported in Belgium. A cat kept at home with a COVID-19-infected owner became clinically ill, exhibiting respiratory problems accompanied by diarrhoea and vomiting. The specific viral sequence of SARS-CoV-2 was detected in the feaces and gastric vomitus of the cat; the sequence was identical to that of the cat owner, again suggesting human-to-cat transmission [25]. In other reports, COVID-19-infected cats were ill after direct contact with their owners, who were also tested COVID-19 positive. All these reports raised a huge public concern as the infected cats could play a role in SARS-CoV-2 transmission. To clear up any inconsistencies, Deng et al. collected 423 cat serum samples (including 48 samples in Wuhan and 42 samples in other 3 cities in China) for detection of the prevalence of SARS-CoV-2 specific antibodies. All samples were serologically negative to SARS-CoV-2 indicating that cats play a limited role in transmission during the COVID-19 pandemic [42] This study is consistent with the work by Temmam et al., who also did not detect antibodies against SARS-CoV-2, nor viral RNA, in a cluster of 21 pets (9 cats and 12 dogs) kept in French households [43]. In conclusion, cats are highly susceptible to SARS-CoV-2, and may contract COVID-19 from pet owners. However, to date, there is no clear evidence that cat-to-human transmission of SARS-CoV-2 can occur. Table 1 shows the summarized information regarding reported COVID-19 on pet cats.

Table 1. Summarized reports of COVID-19 infection in cats kept as pets (from the highest number of tested cats in particular study to the lowest) *

\begin{tabular}{|c|c|c|c|c|}
\hline $\begin{array}{l}\text { Number of } \\
\text { Tested Cats }\end{array}$ & $\begin{array}{l}\text { COVID-19 Tested } \\
\text { Positive Cats }\end{array}$ & Country/Area & $\begin{array}{c}\text { Date } \\
\text { (Month and Year of } \\
\text { Publication) }\end{array}$ & Reference \\
\hline 920 & 6 & Germany & December 2020 & [18] \\
\hline 191 & 11 & Italy & December 2020 & [26] \\
\hline 50 & 6 & Hong Kong, China & December 2020 & [22] \\
\hline 22 & 1 & France & June 2020 & [34] \\
\hline 11 & 3 & The Netherlands & May 2020 & [30] \\
\hline 8 & 1 & Spain & August 2020 & [32] \\
\hline 5 & 5 & Japan & January 2021 & [44] \\
\hline 4 & 10 & Brazil & April 2021 & [45] \\
\hline 4 & 3 & United Kingdom & July 2020 & [41] \\
\hline 4 & 3 & Chile & March 2021 & [24] \\
\hline 3 & 3 & Latvia & February 2021 & [38] \\
\hline 2 & 2 & The Switzerland & March 2021 & [35] \\
\hline 2 & 2 & Canada & January 2021 & [46] \\
\hline 2 & 2 & Argentina & November 2020 & [47] \\
\hline 1 & 1 & Belguim & April 2020 & [25] \\
\hline 1 & 1 & Hong Kong, China & March 2020 & [48] \\
\hline 1 & 1 & Spain & May 2020 & [31] \\
\hline 1 & 1 & Brazil & October 2020 & [49] \\
\hline 1 & 1 & France & May 2020 & [33] \\
\hline 1 & 1 & Italy & February 2021 & [27] \\
\hline 1 & 1 & Italy & September 2020 & [28] \\
\hline 1 & 1 & Greece & December 2020 & [41] \\
\hline 1 & 1 & Croatia & December 2020 & [39] \\
\hline 1 & 1 & Italy & March 2021 & [29] \\
\hline 1 & 1 & Russia & June 2020 & [38] \\
\hline
\end{tabular}

* due to the relatively higher number of naturally acquired SARS-CoV-2 infection in domestic cats in the US (67 studies-February 2021) than in other countries and areas [19], these reports were not included in this table. 


\section{SARS-CoV-2 Isolation in Dogs and Their Zoonotic Potential}

According to the 2019-2020 American Pet Products Associations', over 64 million North American inhabitants own at least one dog [3]. Including European countries, the number of pet dogs has seen a notable increase since 2010; the total amount of dogs reported in 2019 in Europe was estimated at 87.5 million. Germany ranked highest with a dog population of over 10 million in 2019, followed by the United Kingdom (UK) with 9 million [4]. As dogs are often in close contact with humans, especially during the COVID-19 pandemic, it is crucial to determine their susceptibility to SARS-CoV-2 and the impact of virus circulation globally.

To date, there are scarce reports in which a pet dog was tested positive for COVID-19 disease. According to the World Organisation for Animal Health (OIE), 47 cases of SARS$\mathrm{CoV}-2$ have been reported in the US, while in other countries and areas the total notification was 37-as of February 2021 [19]). For instance, in the US (New York), SARS-CoV-2 was detected in housed pet dog (German shepherd) [50]. The dog showed signs of respiratory illness. The dog's owner was also tested positive for COVID-19, suggesting reverse humanto-pet transmission. Furthermore, based on the Agriculture, Fisheries and Conservation Department (AFCD) report of Hong Kong, China, the virus was isolated from 2 of the total 15 dogs investigated (a 17-year-old Pomeranian and a 2.5-year-old German Shepherd). The viral RNA was detected in swabs in the nasal and oral cavities of tested dogs, and one of them developed specific antibodies against SARS-CoV-2. The virus titer was very low in the dog samples, and no clinical signs were observed [51]. Including European countries, SARS-CoV-2 has been isolated from pet dogs housed in the Netherlands [52], Italy [27], Croatia [39], Bosnia and Herzegovina [19], and Germany [53]. In the Netherlands, four domestic pets (one dog and three cats) were tested COVID-19 positive. The dog was suffering severe breathing problems and was euthanized due to the illness [52]. However, in Italy a research group of Patterson et al. reported a large-scale study to assess SARS-CoV-2 infection in 919 companion animals. Although no animals tested PCR positive, approximately $3.3 \%$ dogs had SARS-CoV-2 neutralizing antibody titers [27]. In both cases, dogs appeared to have contracted the virus from their COVID-19 owners, indicating human-to-pet transmission [54]. Several studies have attempted to isolate SARS-CoV-2 from pet dogs but most of them ended without obtaining COVID-19 positive samples. For instance, in France, neither RNA nor antibodies were detected in dogs living in the same room with veterinary students infected with SARS-CoV-2 [34]. Likewise, viral RNA was not detected in 12 dogs housed with confirmed infected individuals in Spain [32]. Taken together, these data suggest that dogs could catch the virus from people, but there was no sign that dogs were transmitting it in the reverse direction [55]. Table 2 shows the summarized information regarding reported COVID-19 on pet dogs.

Table 2. Summarized reports of COVID-19 infections in dogs kept as pets (from the highest number of tested cats in particular study to the lowest one) *.

\begin{tabular}{ccccc}
\hline $\begin{array}{c}\text { Number of } \\
\text { Tested Dogs }\end{array}$ & $\begin{array}{c}\text { COVID-19 Tested } \\
\text { Positive Dogs }\end{array}$ & Country/Area & $\begin{array}{c}\text { Date } \\
\text { (Month and Year of } \\
\text { Publication) }\end{array}$ & Reference \\
\hline 451 & $15^{*}$ & Italy & December 2020 & {$[27]$} \\
18 & 10 & Mexico & December 2020 & {$[56]$} \\
15 & 2 & Mong Kong, China & April 2021 & {$[45]$} \\
9 & 29 & Brazil & November 2020 & {$[47]$} \\
4 & 4 & Argentina & August 2020 & {$[44]$} \\
4 & 4 & Aapan & November 2020 & {$[39]$} \\
3 & 3 & Croatia & May 2020 & {$[52]$} \\
1 & 2 & Germany & October 2020 & {$[57]$} \\
1 & 1 & The Netherlands & February 2021 & {$[19]$} \\
\hline
\end{tabular}

* due to the relatively higher number of naturally acquired SARS-CoV-2 infection in domestic dogs in the US (47 studies-February 2021) than in other countries and areas [19], these reports were not included in this table. 


\section{Feline and Canine Models for SARS-CoV-2}

As cats are susceptible to COVID-19 infection under natural conditions, these companion animals have been explored to study the SARS-CoV-2 pathogenesis and transmission. For instance, to answer the question, which biological mechanisms underlie the phenomenon of potential cat-to-cat transmission, Shi et al. found that juvenile cats were more vulnerable to SARS-CoV-2 infection than the older ones. This variation in viral dissemination in kittens may be reminiscent of the vast tissue tropism and indicate the variation in the disease severity exhibited by SARS-CoV-2 in humans. Viral RNA was detected in the nose and throat of both juvenile and sub-adult cats and caused inflammatory pathology in the respiratory tract of these animals which is consistent with severe COVID-19 in humans [51]. Cat-to-cat transmission under experimental conditions was also documented by Halfmann et al. [59] and Bosco-Lauth et al. [60]. In the first example, cats demonstrated SARS-CoV-2 shedding after 5 days postinfection. The virus was transmitted to naïve cats by close contact. SARS-CoV-2 was isolated from the tissues of upper respiratory tract such as the trachea, nasal turbinate, and esophagus [59]. In the second study, cats were highly susceptible to COVID-19 infection, with a prolonged period of oral and nasal viral shedding, and by direct contact transmitted the virus to other cats [60]. These experimental studies show that cats are not only susceptible to SARS-CoV-2 infection, but they also have a capability to transmit the virus to other cohoused cats.

Cats are not often used as traditional animal models. However, the expression of ACE2 receptors, susceptibility of SARS-CoV-2 under natural conditions, and the ability to transmit the virus from cat to cat are factors encouraging their use as an alternative model to study SARS-CoV-2 pathogenesis [61]. As mentioned in earlier research of Bosco-Lauth et al., experimentally SARS-CoV-2-infected cats developed subclinical pathological changes in the upper respiratory tract early in the course of infection, with lower respiratory tract pathology later following viral clearance. This result suggests that viral infection of cats is not completely benign, and, hence, may be useful as an animal model to mild human COVID-19 infection [60]. Recently, Rudd et al. validated a feline model for SARS-CoV-2 infection; researchers found a significant correlation between the degree of clinical disease identified in infected cats (e.g., coughing, increased respiratory effort, lethargy, and fever) and pulmonary lesions observed due to SARS-CoV-2 infection, mimicking severe COVID-19 pathologies identified in hospitalized people [61]. Despite these promising preliminary results, the utility of cats as animal models for SARS-CoV-2 pathogenesis still requries further studies.

Despite the high identity of canine ACE2 receptors with human ACE2 (83.4\%), dogs are characterized by low susceptibility to SARS-CoV-2. The critical feature of this phenomenon is a single mutation $(\mathrm{H} 34 \mathrm{Y})$ in the canine ACE2 receptor that is not found in human or feline ACE2 [62]. Nevertheless, several reports show the viral infection of dogs under experimental conditions. For instance, three-month-old beagles were intranasally inoculated with an early pandemic strain (SARS-CoV-2/CTan/human/2020/Wuhan), and the viral RNA was detected in rectal swabs. Based on the sera collection and antibody detected by an ELISA, only two virus-inoculated dogs seroconverted. Neither antibodies nor virus has been detected in cohoused dogs [51]. These results are consistent with the study by Bosco-Lauth et al. Dogs did not shed the virus following infection [60]. These and other studies from the current literature lead to the conclusion that dogs are unlikely to be useful as animal models for SARS-CoV-2.

\section{Ferrets Models for SARS-CoV-2}

To date, a natural SARS-CoV-2 infection has been recorded in pet ferrets housed in Spain [63] and Slovenia [64]. In Spain, Giner et al. evaluated the presence of SARS-CoV-2 antibodies in serum samples obtained from 127 household ferrets (Mustela putorius furo). Two ferrets tested positive (1.57\%). SARS-CoV-2 antibodies persisted at detectable levels in a seropositive SARS-CoV-2 domestic ferret beyond 129 days since the first-time antibodies were detected [63]. The first detection of SARS-CoV-2 from pet ferrets was reported in 
Slovenia in late December 2020. The ferret lived in the home with a person suffering from COVID-19 and exhibited gastrointestinal signs [64].

Ferrets are common laboratory models for SARS-CoV-2 due to their high susceptibility to the virus and the ability to transmit it to other ferrets. Independently, Kim et al. [65], Yoo et al. [54], Schlootau et al. [66], Shi et al. [51], and Richard et al. [67] determined that the virus was successfully transmitted to cohoused ferrets (direct contacts) and via the airborne route (indirect contacts). For instance, in a study by Kim et al., experimentally infected ferrets displayed either no clinical symptoms or exhibit elevated body temperature and loss of appetite. Viral RNA was detected in nasal lavages after 2, 4, 6, and 8 dpi (days post-infection). This result, together with the data obtained from other studies regarding the SARS-CoV-2 infection response in ferrets after injection of different viral loads, demonstrated that the virus could replicate in the upper respiratory tract of ferrets, showing a disease pattern similar to that of humans [65]. In addition, unlike mice and rats, ferrets exhibit the cough reflex; as coughing is the most frequently reported symptom in cases of SARS-CoV-2 infection, these animals represent promising models for this virus [68].

Moreover, ferrets have proven to be an appropriate animal model for testing safety and efficacy of SARS-CoV-2 vaccines and antiviral drugs [69]. Park et al. evaluated the antiviral efficacies of three FDA-approved drug candidates against SARS-CoV-2, including lopinavir-ritonavir, hydroxychloroquine sulfate, and emtricitabine-tenofovir. The virus titers in nasal washes, stool specimens and respiratory tissues were similar between all groups treated with drug candidates. Only the emtricitabine-tenofovir-treated group of ferrets showed lower virus titers in nasal washes at 8 days postinfection compared to the PBS-treated control group. Thus, although all antiviral drugs marginally reduced the overall clinical scores of infected ferrets, they did not significantly affect in vivo virus titers [70]. Furthermore, de Vries et al. designed lipopeptide fusion inhibitors that block fusion of the viral and host cell membranes during first step of SARS-CoV-2 infection. Daily intranasal administration of these inhibitors to ferrets completely prevented SARS-CoV-2 direct-contact transmission during 24-h cohousing with infected animals. This study reveals the high potential of lipopetides for effective intranasal prophylaxis to reduce transmission of SARS-CoV-2 [71].

Recently, Blanco-Melo et al. [72] and Liu et al. [73] described antiviral gene signatures induced in ferret models after SARS-CoV-2 infection that can potentially act as antiviral drug targets. Furthermore, Cox et al. demonstrated that treatment of infected ferrets with twice-daily MK-4482/EIDD-2801 significantly reduced upper respiratory tract SARS-CoV-2 load and completely suppressed spread to untreated contact animals. This drug is an analog inhibitor of influenza viruses, EIDD-2801 (or MK-4482), being repurposed against SARS-CoV-2 and is currently in phase II/III clinical trials [74]. These data taken together indicate that ferrets seem to be suitable animal models for studying the pathogenesis of SARS-CoV-2 and COVID-19 drug and vaccine development.

\section{SARS-CoV-2 Isolation in Farmed Minks and Their Zoonotic Potential}

Not only domestic, but also farmed and free-living animals are assumed to be involved in SARS-CoV-2 circulation in the world. SARS-CoV-2 has been detected in farmed minks (Neovison vison) in several European countries including Poland [75-77], the Netherlands [78], Spain [79], Denmark [80], Italy [81], Greece [82], Sweden [83], Latvia [84], and Lithuania [85]. In addition, infected minks have been observed and reported in the US and Canada [86]. To date (i.e., February 2021), SARS-CoV-2 was detected in 409 mink farms worldwide (mostly in Denmark (290 farms) and the Netherlands (69 farms)) [19]. First reports of SARS-CoV-2 isolation from two minks were documented in the Netherlands (April 2020). Viral RNA was detected in the airborne inhalable dust on the mink farms, suggesting that dust and/or droplets are means of transmission between the minks and indicating possible exposure for the workers on the farms [78]. In turn, in the US, 17 cases of SARS-CoV-2 were identified in farmed minks, most of which were located in Utah, with one farm in Wisconsin, and another in Oregon (November 2020). In one case, the probable 
transmission of mink-to-human was observed in a person in close contact with the animals on the farm. Again, this observation indicates the potential threat of mink-to-human transmission of the virus [86]. Therefore, due to the increasing SARS-CoV-2 occurrence in people connected to mink farms, in many countries, preventive elimination of these animals has been implemented (some farms have suspended or definitively terminated their activities). For instance, in Poland, the number of active farms had decreased from 354 in 2020 to 266 at the beginning of 2021. From 28 farms located in different regions of Poland, SARS-CoV-2 was detected in one of them (Pomorskie voivodeship (in the north of Poland)). In this study, 50 throat swabs and 150 serum samples from healthy bred minks were tested. SARS-CoV-2 was isolated from 35 of the 50 throat swabs (70\%) and 45 of the 150 serum samples (30\%) [75]. In the next stage of SARS-CoV monitoring of this mink farm, throat swabs were collected from 91 minks, and in 15 samples, SARS-CoV-2 was detected $(16.5 \%)$ [76]. All these reports taken together show that, considering captive animals, minks possess a high zoonotic potential of SARS-CoV-2 transmission to humans.

\section{Hamsters Models for SARS-CoV-2}

Considering SARS-CoV-2 infections, there is no report of its detection in hamsters under domestic conditions (hamsters as pets). However, these animals are suitable experimental models that provide new aspects of viral pathogenesis and transmissibility as well as successful treatment. Among other studied animal models, the alignment of the ACE2 proteins of humans and hamsters is one of the highest [87]. Thus, the spike protein of SARS-CoV-2 may interact more efficiently with hamster ACE2 than ACE2 from other animal models. In one study, hamsters were intranasally inoculated with SARS-CoV-2, and viral antigens were detected, mainly in the lungs. Notably, SARS-CoV-2 was transmitted efficiently from inoculated hamsters to cohoused naïve hamsters by direct contact and via aerosols. All hamsters recovered, and neutralizing antibodies were detected within 14 dpi [88]. This study was consistent with a study by Boudewijns et al., which aimed to test the mRNA of the hamsters' cytokine profiles. The authors observed induction of interferon- $\gamma$ and pro-inflammatory chemokines/cytokines upon SARS-CoV-2 infection. Primarily inoculated animals developed clinical signs, including lethargy, ruffled fur, hunched back posture, tachypnea, and loss of bodyweight. [89]. Similar results related to viral susceptibility and transmissibility have been reported by Zhang et al. [90] and Lau et al. [91].

The hamster model was also used in studies regarding the effect of age and sex in the severity of the COVID-19 disease in humans. For instance, Osterrieder et al. followed the course of SARS-CoV-2 infection in young and aged Syrian hamsters. Although viral replication in the upper and lower respiratory tract occurred regardless of the animals age, hamsters infected at older ages experienced a more pronounced weight loss than younger animals. Histopathological analysis showed a critical age-dependent influx of immune cells into the lungs, which happened earlier and stronger in young animals [92]. These results observed in hamster models appear to mirror age-dependent differences in human patients.

Lastly, hamsters have proven to be suitable for evaluating vaccines [93-95] and antiviral drugs $[96,97]$ against SARS-CoV-2. With the use of Syrian hamster models, Yuan et al. identified ranitidine bismuth citrate, a commonly used drug for the treatment of Helicobacter pylori infection, as a potent anti-SARS-CoV-2 agent, both in vitro and in vivo. The drug suppressed SARS-CoV-2 replication, leading to decreased viral loads in both upper and lower respiratory tracts and relieved virus-associated pneumonia in tested models [96]. Furthermore, Kaptein et al. determined that a potential candidate of SARS-CoV-2 treatment-favipiravir-significantly reduced infectious virus titers in the lungs of hamsters and markedly improved lung histopathology. This result indicates that favipiravir exhibits a marked protective effect against SARS-CoV-2 in the hamster model [97].

The current dynamics of SARS-CoV-2 affecting humans during the COVID-19 pandemic necessitates further detailed investigations concerning the transmission ability of 
the virus from humans to animals and vice versa. A summary of the data gathered from all studies included in this review is shown in Figure 1. Although in this review several reports regarding SARS-CoV-2 detection in hamsters under experimental infection have been presented, to date, there is no case of natural infection in these animals. Thus hamsters were excluded from this figure.
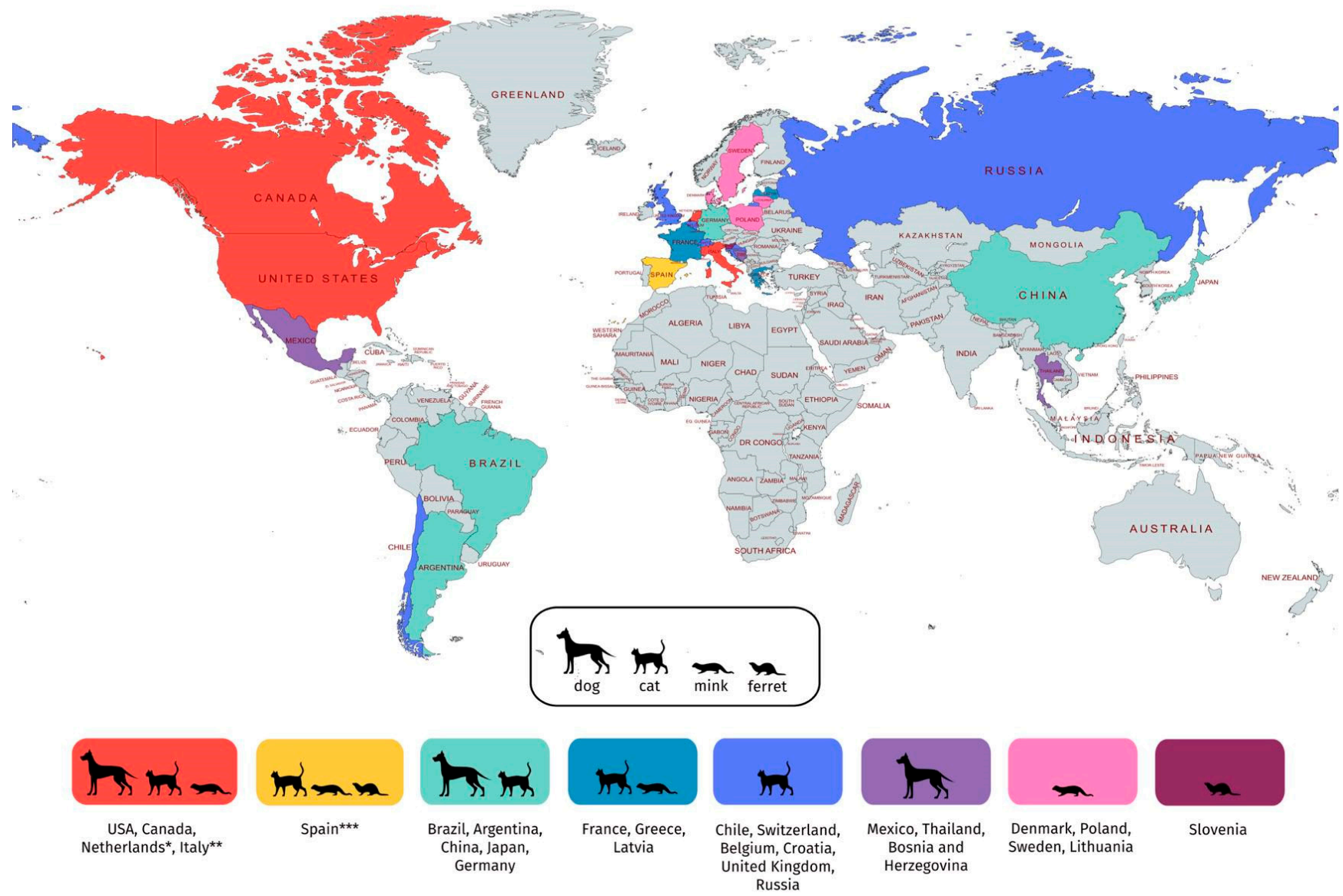

\begin{tabular}{|c|c|c|c|c|}
\hline Animals & cats & dogs & ferrets & farmed minks \\
\hline Type of infection & $\begin{array}{c}\text { Natural } \\
\text { and experimental }\end{array}$ & $\begin{array}{c}\text { Natural } \\
\text { and experimental }\end{array}$ & $\begin{array}{c}\text { Natural } \\
\text { and experimental }\end{array}$ & Natural \\
\hline $\begin{array}{l}\text { Susceptibility } \\
\text { (high/low) }\end{array}$ & High & Low & High & High \\
\hline $\begin{array}{l}\text { Animal-animal transmission } \\
\text { (yes/no) }\end{array}$ & Yes & No & Yes & Yes \\
\hline $\begin{array}{l}\text { Useful as a model } \\
\text { (yes/no) }\end{array}$ & Yes & No & Yes & No \\
\hline
\end{tabular}

Figure 1. Summary of findings of the SARS-CoV-2 infection in companion animals (including cats, dogs, and ferrets) and farmed minks and reports of SARS-CoV-2 natural infection in these animals (25 May 2021) [19]. * Data of dog and cat isolation in the Netherlands are collected from [30,52]; ** Data of dogs isolation in Italy are collected from [27]; ${ }^{* * *}$ Data of pet ferrets isolation in Spain are collected from [63]. We certify that we stays neutral with regard to jurisdictional claims in this map. 


\section{The Need for the Analysis of Epizootiological and Social Risks Analysis in the SARS-CoV-2 Transmission}

One of the critical objectives of the COVID-19 pandemic is thought to be the development of procedures among experts in the field of infectious diseases and ecology to reduce the risk of SARS-CoV-2 transmission in their natural environment. Undoubtedly, the most crucial point of epidemiological proceedings at present should be to limit the transmission of the virus between humans. However, certain social and animal habits and ecological interactions in the environment cannot be ignored. Table 3 summarizes the factors that reduce or increase the risk of transmission of SARS CoV-2 from animals to humans [98-103].

Table 3. Factors influencing the potential risk of transmission of SARS CoV-2 from animals to humans.

\begin{tabular}{cc}
\hline \multicolumn{2}{c}{ The Potential Risk of SARS CoV-2 Transmission } \\
\hline Diminishing Factors & Potentiating Factors \\
\hline Use of restrictive personal protection measures & $\begin{array}{c}\text { Social habits (close contact with wild animals, e.g., traditional } \\
\text { cuisine or natural medicine) }\end{array}$ \\
\hline $\begin{array}{c}\text { Suitable procedures for the transport and handling of } \\
\text { diagnostic samples }\end{array}$ & $\begin{array}{c}\text { Lack of testing procedures and security measures in the transport } \\
\text { of samples }\end{array}$ \\
\hline $\begin{array}{c}\text { Non-invasive methods of collecting samples from animals } \\
\text { that can reduce the risk of e.g., bites }\end{array}$ & Low social and living standards \\
\hline $\begin{array}{c}\text { Information campaigns among the population about the } \\
\text { possible threat and proper conduct of animals }\end{array}$ & $\begin{array}{c}\text { Possibility of contact of domestic animals with wild ones } \\
\text { trade of animals potentially acting as pathogens' carriers }\end{array}$ \\
\hline $\begin{array}{c}\text { Establishing and respecting the law on the circulation and } \\
\text { Reduction in amateur, wildlife tourism and canyoning }\end{array}$ & $\begin{array}{c}\text { The phenomenon of urbanization and globalization } \\
\text { (appearance of wild animals in cities and occupation of new wild } \\
\text { territories by humans) }\end{array}$ \\
\hline
\end{tabular}

\section{Perspectives}

There is a steady increase in the number of reports on the detection of COVID-19 in companion animals around the world. Further studies are required to evaluate the potential of pets to serve as efficient reservoir hosts that can further alter the dynamics of human-to-human transmission. Research collaboration between epidemiologists and veterinary and wildlife specialists is becoming a necessity to evaluate and identify the possible risk factors of transmission between animals and humans. Such cooperation will help to devise efficient strategies for the management of emerging zoonotic diseases. In contrast, we must take care with publicizing the results of studies concerning SARS-CoV-2 isolation from pets in non-scientific communication channels. The impacts of presenting that information to an audience that is not familiar with the scientific community can cause unnecessary panic and catalyze severe consequences for animals and public health [104].

As people and animals can both affected by SARS-CoV-2, it is highly recommended to limit contact with animals if possible. It should be initiated to farmed, companion, freeliving and wildlife animals. If people have to look after their pets, they should maintain good hygiene practices. Animals belonging to owners infected with SARS-CoV-2 should be kept indoors in line with similar lockdown recommendations for humans applicable in the country or area.

\section{Conclusions}

The reports introduced in this review refer to cases of SARS-CoV-2 isolation from pets and statistically inform that, to date, there are no signs that these animals, especially dogs and cats, are a source of infections for humans. The evidence only leads us to cases in which human beings (guardians or handlers) infected by COVID-19 transmitted the virus 
to their pets or charges, cases in which the virus was experimentally inoculated. Given the magnitude of COVID-19 in humans, the lack of any case documenting COVID-19 being transmitted from pets to humans should provide the necessary comfort that our feline and canine friends are not virus propagation factors for humans. However, it is worth noting that several factors, including illegal trade of wildlife animals or the deep anthropization of the territories inhabited by wildlife animals, may have a huge impact on environmental changes, with the potential consequences linked to the appearance of SARS-CoV-2 in humans and their pets due to its transmission from wildlife animals.

Author Contributions: Conceptualization, M.D. and E.P.; writing—original draft preparation, M.D., E.P.; writing-review and editing, M.D., P.K., B.D., S.M., A.J. and E.P.; supervision, E.P.; visualization, M.D.; and funding acquisition, M.D., P.K. and E.P. All authors have read and agreed to the published version of the manuscript.

Funding: This research was funded by Wroclaw Medical University, grant number SUB.A130.21.031 and the Freie Universität Berlin Open Access Publication Fund.

Institutional Review Board Statement: Not applicable.

Informed Consent Statement: Not applicable.

Data Availability Statement: The authors confirm that the data supporting the finding of this study are available within the article.

Acknowledgments: The authors would like to express their gratitude to Florian Heyd (Freie Universität, Berlin, Germany) and Grażyna Gościniak (Wrocław Medical University, Wrocław, Poland) for providing substantive edits and helpful comments that improved the quality of the manuscript.

Conflicts of Interest: The authors declare no conflict of interest.

\section{References}

1. John Hopkins Coronavirus Resource Center. Available online: https://coronavirus.jhu.edu/map.html (accessed on 20 May 2021).

2. Lu, H.; Stratton, C.W.; Tang, Y.W. Outbreak of pneumonia of unknown etiology in Wuhan, China: The mystery and the miracle. J. Med. Virol. 2020, 92, 401-402. [CrossRef] [PubMed]

3. Morgan, L.; Protopopova, A.; Birkler, R.I.D.; Itin-Schwartz, B.; Sutton, G.A.; Gamliel, A.; Yakobson, B.; Raz, T. Human-dog relationships during the COVID-19 pandemic: Booming dog adoption during social isolation. Humanit. Soc. Sci. Commun. 2020, 7, 155. [CrossRef]

4. Statista. How Has Your Pet Ownership Been Affected by COVID-19? Available online: https://www.statista.com/statistics/1191 395/pet-ownership-status-due-to-covid-19-in-the-us / (accessed on 17 November 2020).

5. Wyborcza.pl. Jasna Strona Pandemii. Coraz Mniej Zwierzat w Schroniskach, a Więcej w Domach. Available online: https: / / trojmiasto.wyborcza.pl/trojmiasto/7,35612,26973696,mniej-czworonogow-w-schroniskach-wiecej-w-domach-dobra-strona. html?disableRedirects=true (accessed on 14 April 2021).

6. Zhou, P.; Yang, X.L.; Wang, X.G.; Hu, B.; Zhang, L.; Zhang, W.; Si, H.R.; Zhu, Y.; Li, B.; Huang, C.L.; et al. A pneumonia outbreak associated with a new coronavirus of probable bat origin. Nature 2020, 579, 270-273. [CrossRef]

7. Li, L.-L.; Wang, J.-L.; Ma, X.-H.; Li, J.-S.; Yang, X.-F.; Shi, W.-F.; Duan, Z.-J. A novel SARS-CoV-2 related virus with complex recombination isolated from bats in Yunnan province, China. bioRxiv 2021, 17, 435823.

8. Singla, R.; Mishra, A.; Joshi, R.; Jha, S.; Sharma, A.R.; Upadhyay, S.; Sarma, P.; Prakash, A.; Medhi, B. Human animal interface of SARS-CoV-2 (COVID-19) transmission: A critical appraisal of scientific evidence. Vet. Res. Commun. 2020, 44, 119-130. [CrossRef] [PubMed]

9. Martina, B.E.; Haagmans, B.L.; Kuiken, T.; Fouchier, R.A.; Rimmelzwaan, G.F.; van Amerongen, G.; Peiris, J.S.; Lim, W.; Osterhaus, A.D. SARS virus infection of cats and ferrets. Nature 2003, 425, 915-934. [CrossRef] [PubMed]

10. Sharma, A.; Tiwari, S.; Deb, M.K.; Marty, J.L. Severe acute respiratory syndrome coronavirus-2 (SARS-CoV-2): A global pandemic and treatment strategies. Int. J. Antimicrob. Agents 2020, 56, 106054. [CrossRef]

11. Qian, Z.; Dominguez, S.R.; Holmes, K.V. Role of the spike glycoprotein of human Middle East respiratory syndrome coronavirus (MERS-CoV) in virus entry and syncytia formation. PLoS ONE 2013, 8, e76469. [CrossRef] [PubMed]

12. Dias, H.G.; Resck, M.E.B.; Caldas, G.C.; Resck, A.F.; da Silva, N.V.; Dos Santos, A.M.V.; Sousa, T.D.C.; Ogrzewalska, M.H.; Siqueira, M.M.; Pauvolid-Corrêa, A.; et al. Neutralizing antibodies for SARS-CoV-2 in stray animals from Rio de Janeiro, Brazil. PLoS ONE 2021, 16, e0248578. [CrossRef]

13. Koopmans, M. SARS-CoV-2 and the human-animal interface: Outbreaks on mink farms. Lancet. Infect. Dis. 2021, 21, 18-19. [CrossRef]

14. Sreenivasan, C.C.; Milton, T.; Wang, D.; Li, F. Susceptibility of livestock and companion animals to COVID-19. J. Med. Virol. 2021, 93, 1351-1360. [CrossRef] 
15. Luan, J.; Lu, Y.; Jin, X.; Zhang, L. Spike protein recognition of mammalian ACE2 predicts the host range and an optimized ACE2 for SARS-CoV-2 infection. Biochem. Biophys. Res. Commun. 2020, 526, 165-169. [CrossRef] [PubMed]

16. Zhao, X.; Chen, D.; Szabla, R.; Zheng, M.; Li, G.; Du, P.; Zheng, S.; Li, X.; Song, C.; Li, R.; et al. Broad and Differential Animal Angiotensin-Converting Enzyme 2 Receptor Usage by SARS-CoV-2. J. Virol. 2020, 94, e00940-20. [CrossRef]

17. American Veterinary Medical Association. US Pet Ownership Statistics. Available online: https://www.avma.org/resourcestools / reports-statistics/us-pet-ownership-statistics (accessed on 19 October 2020).

18. Vets Begin Offering Coronavirus Tests for PETS in Germany, and Warn Cats Are the Most Likely to Be Infected. Available online: https:/ / www.dailymail.co.uk/news/article-8195763/Vets-begin-offering-coronavirus-tests-PETS-Germany.html (accessed on 13 October 2020).

19. American Veterinary Medical Association. In-Depth Summary of Reports of Naturally Acquired SARS-CoV-2 Infections in Domestic Animals and Farmed or Captive Wildlife. 2021. Available online: https:/ / www.avma.org/resources-tools/animalhealth-and-welfare/covid-19/ depth-summary-reports-naturally-acquired-sars-cov-2 (accessed on 24 May 2021).

20. Peltz, J. 2 Cats in NY Become First US Pets to Test Positive for Virus. 2020. Available online: https://apnews.com/37328ab8db093 b8346e26e1840b48af8 (accessed on 13 September 2020).

21. COVID-19 Update (70): China (Hong Kong) Cat, Pets and Stock. 2020. Available online: http://promedmail.org/post/20200326 .7173286 (accessed on 13 September 2020).

22. Barrs, V.R.; Peiris, M.; Tam, K.W.S.; Law, P.Y.T.; Brackman, C.J.; To, E.M.W.; Yu, V.; Chu, D.; Perera, R.A.P.M.; Sit, T.H.C. SARSCoV-2 in Quarantined Domestic Cats from COVID-19 Households or Close Contacts, Hong Kong, China. Emerg. Infect. Dis. 2020, 26, 3071-3074. [CrossRef]

23. Zhang, Q.; Zhang, H.; Gao, J.; Huang, K.; Yang, Y.; Hui, X.; He, X.; Li, C.; Gong, W.; Zhang, Y.; et al. Serological survey of SARS-CoV-2 in cat in Wuhan. Emerg. Microbes Infect. 2020, 9, 2013-2019. [CrossRef] [PubMed]

24. Neira, V.; Brito, B.; Agüero, B.; Berrios, F.; Valdés, V.; Gutierrez, A.; Ariyama, N.; Espinoza, P.; Retamal, P.; Holmes, E.C.; et al. A household case evidences shorter shedding of SARS-CoV-2 in naturally infected cats compared to their human owners. Emerg. Microbes Infect. 2021, 10, 376-383. [CrossRef] [PubMed]

25. Cat in Belgium Tests Positive for Coronavirus after Being Infected by Owner, Experts Say 'Rare Case'. Available online: https:/ / www.india.com/viral/ cat-in-belgium-tests-positive-for-coronavirus-after-being-infected-by-owner-experts-say-rarecase-3983980/ (accessed on 30 March 2021).

26. Pagani, G.; Lai, A.; Bergna, A.; Rizzo, A.; Stranieri, A.; Giordano, A.; Paltrinieri, S.; Lelli, D.; Decaro, N.; Rusconi, S.; et al. Human-to-Cat SARS-CoV-2 Transmission: Case Report and Full-Genome Sequencing from an Infected Pet and Its Owner in Northern Italy. Pathogens 2021, 10, 252. [CrossRef]

27. Patterson, E.I.; Elia, G.; Grassi, A.; Giordano, A.; Desario, C.; Medardo, M.; Smith, S.L.; Anderson, E.R.; Prince, T.; Patterson, G.T.; et al. Evidence of exposure to SARS-CoV-2 in cats and dogs from households in Italy. Nat. Commun. 2020, 11, 6231. [CrossRef]

28. Musso, N.; Costantino, A.; La Spina, S.; Finocchiaro, A.; Andronico, F.; Stracquadanio, S.; Liotta, L.; Visalli, R.; Emmanuele, G. New SARS-CoV-2 Infection Detected in an Italian Pet Cat by RT-qPCR from Deep Pharyngeal Swab. Pathogens 2020, 9, 746. [CrossRef] [PubMed]

29. Klaus, J.; Palizzotto, C.; Zini, E.; Meli, M.L.; Leo, C.; Egberink, H.; Zhao, S.; Hofmann-Lehmann, R. SARS-CoV-2 Infection and Antibody Response in a Symptomatic Cat from Italy with Intestinal B-Cell Lymphoma. Viruses 2021, 13, 527. [CrossRef]

30. Staff, R. Dutch Dog, Three Cats Infected with Coronavirus: Minister. Available online: https://www.reuters.com/article/ ushealth-coronavirus-netherlands-pets/dutch-dog-three-cats-infected-with-coronavirus-minister-idUSKBN22R2EN (accessed on 30 December 2020).

31. Domínguez, N. Spain Records Its First Case of a Cat with Coronavirus. Available online: https://english.elpais.com/society/20 20-05-08/spain-records-its-first-case-of-a-cat-with-coronavirus.html (accessed on 13 October 2020).

32. Ruiz-Arrondo, I.; Portillo, A.; Palomar, A.M.; Santibáñez, S.; Santibáñez, P.; Cervera, C.; Oteo, J.A. Detection of SARS-CoV-2 in pets living with COVID-19 owners diagnosed during the COVID-19 lockdown in Spain: A case of an asymptomatic cat with SARS-CoV-2 in Europe. Transbound. Emerg. Dis. 2021, 68, 973-976. [CrossRef] [PubMed]

33. Libert, L. Feline Good: French Cat Survives Coronavirus Infection. 2020. Available online: https://www.reuters.com/article/ us-health-coronavirus-france-cat/feline-good-french-cat-survives-coronavirus-infection-idUSKBN23427J?il=0 (accessed on 16 November 2020).

34. Sailleau, C.; Dumarest, M.; Vanhomwegen, J.; Delaplace, M.; Caro, V.; Kwasiborski, A.; Hourdel, V.; Chevaillier, P.; Barbarino, A.; Comtet, L.; et al. First detection and genome sequencing of SARS-CoV-2 in an infected cat in France. Transbound. Emerg. Dis. 2020, 67, 2324-2328. [CrossRef] [PubMed]

35. Klaus, J.; Meli, M.L.; Willi, B.; Nadeau, S.; Beisel, C.; Stadler, T.; Egberink, H.; Zhao, S.; Lutz, H.; Riond, B.; et al. Detection and Genome Sequencing of SARS-CoV-2 in a Domestic Cat with Respiratory Signs in Switzerland. Viruses 2021, 13, 496. [CrossRef] [PubMed]

36. The World Organization for Animal Health. A More Recent Case Has Been Detected in a Cat in Russia, But No Clinical Data Are Available. Available online: https://www.oie.int/en/scientific-expertise/specific-information-and-recommendations/ questions-and-answers-on-2019novel-coronavirus/events-in-animals/ (accessed on 2 February 2021).

37. The World Organization for Animal Health. Available online: https:/ / wahis.oie.int/\#/ report-info?reportId=32666 (accessed on 27 April 2021). 
38. The World Organization for Animal Health. Available online: https://wahis.oie.int/\#/ report-info? reportId=31360 (accessed on 21 March 2021).

39. The World Organization for Animal Health. Available online: https://www.oie.int/fileadmin/Home/MM/Greece_cat_23.12.20 20.pdf (accessed on 22 March 2021).

40. The World Organisation for Animal Health. Available online: https:/ / wahis.oie.int/\#/report-info?reportId=15477 (accessed on 22 March 2021).

41. Hosie, M.J.; Epifano, I.; Herder, V.; Orton, R.J.; Stevenson, A.; Johnson, N.; MacDonald, E.; Dunbar, D.; McDonald, M.; Howie, F.; et al. Respiratory disease in cats associated with human-to-cat transmission of SARS-CoV-2 in the UK. bioRxiv 2020. [CrossRef]

42. Deng, J.; Liu, Y.; Sun, C.; Bai, J.; Sun, J.; Hao, L.; Li, X.; Tian, K. SARS-CoV-2 Serological Survey of Cats in China before and after the Pandemic. Virol. Sin. 2020, 35, 846-848. [CrossRef]

43. Temmam, S.; Barbarino, A.; Maso, D.; Behillil, S.; Enouf, V.; Huon, C.; Jaraud, A.; Chevallier, L.; Backovic, M.; Pérot, P.; et al. Absence of SARS-CoV-2 infection in cats and dogs in close contact with a cluster of COVID-19 patients in a veterinary campus. One Health 2020, 10, 100164. [CrossRef]

44. Japan Confirms First Cases of COVID-19 in Pets as Two Dogs Test Positive. Available online: https://www.japantimes.co.jp/ news/2020/08/03/national/japan-coronavirus-dogs/ (accessed on 24 April 2021).

45. Calvet, G.A.; Pereira, S.A.; Ogrzewalska, M.; Pauvolid-Corrêa, A.; Resende, P.C.; Tassinari, W.S.; Costa, A.P.; Keidel, L.O.; da Rocha, A.S.B.; da Silva, M.F.B.; et al. Investigation of SARS-CoV-2 infection in dogs and cats of humans diagnosed with COVID-19 in Rio de Janeiro, Brazil. PLoS ONE 2021, 16, e0250853. [CrossRef] [PubMed]

46. 1.1.6 of The Terrestrial Animal Health Code of the World Organization for Animal Health. Available online: https://www.oie. int/fileadmin/Home/MM/Canada_cat_10.02.2021.pdf (accessed on 23 March 2021).

47. Bonilauri, P.; Rugna, G. Animal Coronaviruses and SARS-COV-2 in Animals, What Do We Actually Know? Life 2021, 11, 123. [CrossRef]

48. Hong Kong's Information Services Department Pet Cat Tests Positive for COVID-19. Available online: http://www.news.gov.hk/ (accessed on 5 April 2021).

49. Researchers Identify First Cat with Coronavirus in Brazil. Available online: https://www1.folha.uol.com.br/internacional/en/ scienceandhealth/2020/10/researchers-identify-first-cat-with-coronavirus-in-brazil.shtml (accessed on 23 March 2021).

50. Animal and Plant Health Inspection Service, U.S. Department of Agriculture. Available online: https: / / www.aphis.usda.gov/ aphis/newsroom/stakeholder-info/sa_by_date/sa-2020/sa-06/sars-cov-2-dog (accessed on 26 April 2021).

51. Shi, J.; Wen, Z.; Zhong, G.; Yang, H.; Wang, H.; Huang, B.; Liu, R.; He, X.; Shuai, L.; Sun, Z.; et al. Susceptibility of ferrets, cats, dogs, and other domesticated animals to SARS-coronavirus 2. Science 2020, 368, 1016-1020. [CrossRef]

52. Dutch House Pets Test Positive for Coronavirus. Available online: https://www.dw.com/en/dutch-house-pets-test-positive-forcoronavirus/a-53460111 (accessed on 13 September 2020).

53. The World Organization for Animal Health. Available online: https://www.oie.int/fileadmin/Home/MM/Germany_1_ December.pdf (accessed on 13 September 2020).

54. Yoo, H.S.; Yoo, D. COVID-19 and veterinarians for one health, zoonotic- and reverse-zoonotic transmissions. J. Vet. Sci. 2020, 21. [CrossRef]

55. Sit, T.H.C.; Brackman, C.J.; Ip, S.M.; Tam, K.W.S.; Law, P.Y.T.; To, E.M.W.; Yu, V.Y.T.; Sims, L.D.; Tsang, D.N.C.; Chu, D.K.W.; et al. Infection of dogs with SARS-CoV-2. Nature 2020, 586, 776-778. [CrossRef]

56. The World Organization for Animal Health. Available online: https://wahis.oie.int/\#/report-info? reportId=31060 (accessed on 16 April 2021).

57. SARS-CoV-2 Infected Dog: Canada. Available online: https://www.wormsandgermsblog.com/2020/10/articles/animals/dogs/ sars-cov-2-infected-dog-canada/ (accessed on 13 March 2021).

58. The World Organization for Animal Health. Available online: https:/ / wahis.oie.int/\#/ report-info? reportId=33320 (accessed on 25 May 2021).

59. Halfmann, P.J.; Hatta, M.; Chiba, S.; Maemura, T.; Fan, S.; Takeda, M.; Kinoshita, N.; Hattori, S.I.; Sakai-Tagawa, Y.; IwatsukiHorimoto, K.; et al. Transmission of SARS-CoV-2 in Domestic Cats. N. Engl. J. Med. 2020, 383, 592-594. [CrossRef]

60. Bosco-Lauth, A.M.; Hartwig, A.E.; Porter, S.M.; Gordy, P.W.; Nehring, M.; Byas, A.D.; VandeWoude, S.; Ragan, I.K.; Maison, R.M.; Bowen, R.A. Experimental infection of domestic dogs and cats with SARS-CoV-2: Pathogenesis, transmission, and response to reexposure in cats. Proc. Natl. Acad. Sci. USA 2020, 117, 26382-26388. [CrossRef] [PubMed]

61. Rudd, J.M.; Selvan, M.T.; Cowan, S.; Midkiff, C.C.; Ritchey, J.W.; Miller, C.A. Clinicopathologic features of a feline SARS-CoV-2 infection model parallel acute COVID-19 in humans. bioRxiv 2021, 4, 439863.

62. Guan, W.-J.; Ni, Z.-Y.; Hu, Y.; Liang, W.-H.; Ou, C.-Q.; He, J.-X.; Liu, L.; Shan, H.; Lei, C.-L.; Hui, D.S.C.; et al. Clinical characteristics of coronavirus disease 2019 in China. N. Engl. J. Med. 2020, 382, 1708-1720. [CrossRef]

63. Giner, J.; Villanueva-Saz, S.; Tobajas, A.P.; Pérez, M.D.; González, A.; Verde, M.; Yzuel, A.; García-García, A.; Taleb, V.; Lira-Navarrete, E.; et al. SARS-CoV-2 Seroprevalence in Household Domestic Ferrets (Mustela putorius furo). Animals 2021, 11, 667. [CrossRef]

64. The World Organization for Animal Health. Available online: https:/ / wahis.oie.int/\#/ report-info? reportId=28156 (accessed on 24 March 2021).

65. Kim, Y.I.; Kim, S.G.; Kim, S.M.; Kim, E.H.; Park, S.J.; Yu, K.M.; Chang, J.H.; Kim, E.J.; Lee, S.; Casel, M.A.B.; et al. Infection and Rapid Transmission of SARS-CoV-2 in Ferrets. Cell. Host Microbe 2020, 27, 704-709.e2. [CrossRef] 
66. Schlottau, K.; Rissmann, M.; Graaf, A.; Schon, J.; Sehl, J.; Wylezich, C.; Hoper, D.; Mettenleiter, T.C.; Balkema-Buschmann, A.; Harder, T.; et al. SARS-CoV-2 in fruit bats, ferrets, pigs, and chickens: An experimental transmission study. Lancet. Microbe 2020, 1, e218-e225. [CrossRef]

67. Richard, M.; Kok, A.; de Meulder, D.; Bestebroer, T.M.; Lamers, M.M.; Okba, N.M.A.; Fentener van Vlissingen, M.; Rockx, B.; Haagmans, B.L.; Koopmans, M.; et al. SARS-CoV-2 is transmitted via contact and via the air between ferrets. Nat. Commun. 2020, 11, 3496. [CrossRef] [PubMed]

68. Rosa, R.B.; Dantas, W.M.; do Nascimento, J.C.F.; da Silva, M.V.; de Oliveira, R.N.; Pena, L.J. In Vitro and In Vivo Models for Studying SARS-CoV-2, the Etiological Agent Responsible for COVID-19 Pandemic. Viruses 2021, 13, 379. [CrossRef] [PubMed]

69. Marsh, G.A.; McAuley, A.J.; Brown, S.; Pharo, E.A.; Crameri, S.; Au, G.G.; Baker, M.L.; Barr, J.A.; Bergfeld, J.; Bruce, M.P.; et al. In vitro characterisation of SARS-CoV-2 and susceptibility of domestic ferrets (Mustela putorius furo). Transbound. Emerg. Dis. 2021. [CrossRef]

70. Park, S.J.; Yu, K.M.; Kim, S.M.; Kim, E.H.; Kim, S.G.; Kim, E.J.; Casel, A.B.; Rollon, R.; Jang, S.G.; Lee, M.H.; et al. Antiviral Efficacies of FDA-Approved Drugs against SARS-CoV-2 Infection in Ferrets. mBio 2020, 11, e01114-20. [CrossRef] [PubMed]

71. De Vries, R.D.; Schmitz, K.S.; Bovier, F.T.; Predella, C.; Khao, J.; Noack, D.; Haagmans, B.L.; Herfst, S.; Stearns, K.N.; Drew-Bear, J.; et al. Intranasal fusion inhibitory lipopeptide prevents direct-contact SARS-CoV-2 transmission in ferrets. Science 2021, 371, 1379-1382. [CrossRef]

72. Blanco-Melo, D.; Nilsson-Payant, B.E.; Liu, W.C.; Uhl, S.; Hoagland, D.; Møller, R.; Jordan, T.X.; Oishi, K.; Panis, M.; Sachs, D.; et al. Imbalanced host response to SARS-CoV-2 drives development of COVID-19. Cell 2020, 181, 1036-1045.e9. [CrossRef]

73. Liu, H.L.; Yeh, I.J.; Phan, N.N.; Wu, Y.H.; Yen, M.C.; Hung, J.H.; Chiao, C.C.; Chen, C.F.; Sun, Z.; Jiang, J.Z.; et al. Gene signatures of SARS-CoV/SARS-CoV-2-infected ferret lungs in short- and long-term models. Infect. Genet. Evol. 2020, 85, 104438. [CrossRef]

74. Cox, R.M.; Wolf, J.D.; Plemper, R.K. Therapeutic MK-4482/EIDD-2801 Blocks SARS-CoV-2 Transmission in Ferrets. Res. Sq. 2020. [CrossRef]

75. Domańska-Blicharz, K.; Orłowska, A.; Smreczak, M.; Niemczuk, K.; Iwan, E.; Bomba, A.; Lisowska, A.; Opolska, J.; Trębas, P.; Potyrało, P.; et al. Mink SARS-CoV-2 Infection in Poland-Short Communication. J. Vet. Res. 2021, 65, 1-5. [CrossRef] [PubMed]

76. Rabalski, L.; Kosinski, M.; Smura, T.; Aaltonen, K.; Kant, R.; Sironen, T.; Szewczyk, B.; Grzybek, M. Detection and molecular characterisation of SARS-CoV-2 2 in farmed mink (Neovision vision) in Poland. bioRxiv 2020, 12, 422670.

77. Rabalski, L.; Kosinski, M.; Mazur-Panasiuk, N.; Szewczyk, B.; Bienkowska-Szewczyk, K.; Kant, R.; Sironen, T.; Pyrć, K.; Grzybek, M. Zoonotic spillover of SARS-CoV-2: Mink-adapted virus in humans. bioRxiv 2021, 3, 433713.

78. Oreshkova, N.; Molenaar, R.J.; Vreman, S.; Harders, F.; Oude Munnink, B.B.; Hakze-van der Honing, R.W.; Gerhards, N.; Tolsma, P.; Bouwstra, R.; Sikkema, R.S.; et al. SARS-CoV-2 infection in farmed minks, the Netherlands, April and May 2020. Eurosurveillance 2020, 25, 2001005. [CrossRef] [PubMed]

79. The World Organization for Animal Health. Available online: https://www.oie.int/fileadmin/Home/MM/Informe_visones_ OIE_16.07.20_.pdf (accessed on 23 September 2020).

80. The World Organization for Animal Health. Available online: https://www.oie.int/fileadmin/Home/MM/Update_1_Letter_to_ OIE_about_the_COVID-19_situation_in_Denmark.pdf (accessed on 13 September 2020).

81. The World Organization for Animal Health. Available online: https://www.oie.int/fileadmin/Home/MM/Italy_COVID_30.10. 2020.pdf (accessed on 23 September 2020).

82. The World Organization for Animal Health. Available online: https://www.oie.int/fileadmin/Home/MM/Greece_First_ COVID-19_case_in_mink_OIE.pdf (accessed on 23 September 2020).

83. The World Organization for Animal Health. Available online: https://www.oie.int/fileadmin/Home/MM/Sweden_Update_1_ 29.10.2020.pdf (accessed on 23 September 2020).

84. The World Organization for Animal Health. Available online: https://wahis.oie.int/\#/report-info?reportId=32950 (accessed on 25 May 2021).

85. United States Department of Agriculture, Foreign Agricultural Service. Available online: https://apps.fas.usda.gov/newgainapi/ api/Report/DownloadReportByFileName?fileName=COVID-19\%20Outbreak\%20on\%20Lithuanian\%20Mink\%20Farm_ Warsaw_Lithuania_11-30-2020 (accessed on 24 March 2021).

86. The World Organisation for Animal Health (OIE): Covid-19 Portal: Events in Animals 15 February 2021 Update. Available online: https://www.oie.int/scientific-expertise/specific-information-andrecommendations/questions-and-answers-on-2019 novel-coronavirus/events-in-animals / (accessed on 3 March 2021).

87. Lakdawala, S.S.; Menachery, V.D. The search for a COVID-19 animal model. Science 2020, 368, 942-943. [CrossRef]

88. Sia, S.F.; Yan, L.M.; Chin, A.W.H.; Fung, K.; Choy, K.T.; Wong, A.Y.L.; Kaewpreedee, P.; Perera, R.A.P.M.; Poon, L.L.M.; Nicholls, J.M.; et al. Pathogenesis and transmission of SARS-CoV-2 in golden hamsters. Nature 2020, 583, 834-838. [CrossRef]

89. Boudewijns, R.; Thibaut, H.J.; Kaptein, S.J.F.; Li, R.; Vergote, V.; Seldeslachts, L.; Van Weyenbergh, J.; De Keyzer, C.; Bervoets, L.; Sharma, S.; et al. STAT2 signaling restricts viral dissemination but drives severe pneumonia in SARS-CoV-2 infected hamsters. Nat. Commun. 2020, 11, 5838. [CrossRef] [PubMed]

90. Zhang, C.; Guo, Z.; Li, N.; Cui, H.; Meng, K.; Liu, L.; Zhao, L.; Zhang, S.; Qin, C.; Liu, J.; et al. Impact of Prior Infection on Protection and Transmission of SARS-CoV-2 in Golden Hamsters. bioXriV 2021, 1, 428920.

91. Lau, S.Y.; Wang, P.; Mok, B.W.; Zhang, A.J.; Chu, H.; Lee, A.C.; Deng, S.; Chen, P.; Chan, K.H.; Song, W.; et al. Attenuated SARS-CoV-2 variants with deletions at the S1/S2 junction. Emerg. Microbes Infect. 2020, 9, 837-842. [CrossRef] 
92. Osterrieder, N.; Bertzbach, L.D.; Dietert, K.; Abdelgawad, A.; Vladimirova, D.; Kunec, D.; Hoffmann, D.; Beer, M.; Gruber, A.D.; Trimpert, J. Age-Dependent Progression of SARS-CoV-2 Infection in Syrian Hamsters. Viruses 2020, 12, 779. [CrossRef]

93. Mohandas, S.; Shete, A.; Abraham, P.; Mohan, K. Immunogenicity and protective efficacy of BBV152: A whole virion inactivated SARS CoV-2 vaccine in the Syrian hamster model. Res. Sq. 2020, 24, 102054.

94. Vitner, E.B.; Israeli, O.; Milrot, E.; Stein, D.; Cohen-gihon, I.; Lazar, S.; Gutman, H.; Lupu, E.; David, E.B.; Sittner, A.; et al. A single dose of recombinant VSV- $\Delta$ G-spike vaccine provides protection against SARS-CoV-2 challenge Yfat. Nat. Commun. 2020, 11, 6402.

95. Tostanoski, L.H.; Wegmann, F.; Martinot, A.J.; Loos, C.; McMahan, K.; Mercado, N.B.; Yu, J.; Chan, C.N.; Bondoc, S.; Starke, C.E.; et al. Ad26 vaccine protects against SARS-CoV-2 severe clinical disease in hamsters. Nat. Med. 2020, 26, 1694-1700. [CrossRef]

96. Yuan, S.; Wang, R.; Chan, J.F.W.; Zhang, A.J.; Cheng, T.; Chik, K.K.H.; Ye, Z.W.; Wang, S.; Lee, A.C.Y.; Jin, L.; et al. Metallodrugranitidine bismuth citrate suppresses SARS-CoV-2 replication and relieves virus-associated pneumonia in Syrian hamsters. Nat. Microbiol. 2020, 5, 1439-1448. [CrossRef] [PubMed]

97. Kaptein, S.J.F.; Jacobs, S.; Langendries, L.; Seldeslachts, L.; ter Horst, S.; Liesenborghs, L.; Hens, B.; Vergote, V.; Heylen, E.; Barthelemy, K.; et al. Favipiravir at high doses has potent antiviral activity in SARS-CoV-2-infected hamsters, whereas hydroxychloroquine lacks activity. Proc. Natl. Acad. Sci. USA 2020, 117, 26955-26965. [CrossRef] [PubMed]

98. Oliva, K.J.; Cryan, P.M.; Amman, B.R.; Baric, R.S.; Blehert, D.S.; Brook, C.E.; Calisher, C.H.; Castle, K.T.; Coleman, J.T.H.; Daszak, P.; et al. Possibility for reverse zoonotic transmission of SARS-CoV-2 to free-ranging wildlife: A case study of bats. PLoS Pathog. 2020, 3, e1008758.

99. Amman, B.R.; Schuh, A.J.; Towner, J.S. Ebola virus field sample collection. Methods. Mol. Biol. 2017, 1628, 373-393. [PubMed]

100. Wood, J.L.N.; Leach, M.; Waldman, L.; MacGregor, H.; Fooks, A.R.; Jones, K.E. A framework for the study of zoonotic disease emergence and its drivers: Spillover of bat pathogens as a case study. Philos. Trans. R. Soc. B 2012, 367, 2881-2892. [CrossRef] [PubMed]

101. Daszak, P. A qualitative study of zoonotic risk factors among rural communities in southern China. Int. Health 2020, 12, 77-85.

102. Benvenuto, D.; Giovanetti, M.; Ciccozzi, A.; Spoto, S.; Angeletti, S.; Ciccozzi, M. The 2019-new coronavirus epidemic: Evidence for virus evolution. J. Med. Virol. 2020, 92, 455-459. [CrossRef] [PubMed]

103. Parry, N. COVID-19 and pets: When pandemic meets panic. Forensic Sci. Int. 2020, 2, 100090. [CrossRef]

104. Overgaauw, P.A.M.; Vinke, C.M.; van Hagen, M.A.E.; Lipman, L.J.A. A One Health Perspective on the Human-Companion Animal Relationship with Emphasis on Zoonotic Aspects. Int. J. Environ. Res. Public Health 2020, 17, 3789. [CrossRef] 